Ewa Nowak

Uniwersytet im. Adama Mickiewicza, Poznań

e-mail: ewanowak@amu.edu.pl

\title{
Antropologia niepełnosprawności: narodziny, schyłek i odrodzenie paradygmatu
}

DOI: http://dx.doi.org/10.12775/RF.2017.027

\section{Wprowadzenie ${ }^{1}$}

Gdyby wzorem Michela Foucault genealogicznie zbadać i spisać 'historię' niepełnosprawności, liczyłaby ona wiele tomów. Owo polisemiczne pojęcie wyewoluowało z rzymskiej „monstrualności” i nowożytnego „inwalidztwa”, a jego znaczenie zmieniało się wraz z ezoterycznym i scholastycznym, później zaś - naukowym i humanistycznym rozpoznaniem rozmaitych perypetii ludzkiego ciała. Można te perypetie podzielić na morfologiczne, morfologiczno-fizjologiczne, funkcjonalne i wreszcie praktyczne. Te dystynkcje są płynne, ale współczesna świadomość nadal powiela pozytywistyczny² schemat fizyczne/psychiczne, nierzadko pomijając duchową i społeczną aurę niepełnosprawności, nie mówiąc już o fenomenologicznym doświadczeniu niepełnosprawności i towarzyszącej jej narracji antropologicznej. Wbrew definicji WHO niepełnosprawność nie jest więc jedynie kolejną z rzędu jednostką chorobo-

1 Artykuł powstał w ramach grantu NCN Opus 9 nr 2015/17/B/HS1/02381 pt. „Ewolucja jaźni: przyczynek do rewizji posthumanizmu”. Autorka składa Narodowemu Centrum Nauki podziękowania za wsparcie i sfinansowanie prowadzonych przez nią badań.

2 Wyznaczający klasyfikację nauk medycznych. 
wą dającą się wyczerpująco zdefiniować w kategoriach funkcjonalizmu ${ }^{3}$ lub antropologii medycznej. Nie jest też przedmiotem samej tylko antropologii kulturowej i etnologii, eksplorujących „odmienność" (otherness) ${ }^{4}$. Niepełnosprawność stanowi także przedmiot badań dla antropologii filozoficznej5. Uważam ponadto, że przy silnym rozdrobnieniu i specjalizacji nauk filozofia jest $\mathrm{w}$ stanie unaocznić 'paradygmat niepełnosprawności' całościowo i dynamicznie. Dynamika ta oznacza rozwój, ale nie "postęp": ludzkość bowiem nigdy jeszcze nie osiągnęła stanu, w którym wspólistnienie tego, co pełno- i niepełnosprawne byłoby zadowalające z pragmatycznego, a przede wszystkim etycznego punktu widzenia.

\section{Archetypy cielesności i ich dziedzictwo}

Homer, od którego pochodzą najstarsze greckie przekazy o ciele, jego budowie, tytanicznej sile i sprawności, a z drugiej strony - ułomności i niepełnosprawności - sam miał być pozbawiony wzroku, a tym samym „widzieć prawdziwie" ${ }^{\prime 6}$. Niewidomy jest też Demodokus (dosł. sławiony przez lud), snujący śpiewną opowieść o Troi znaną jako Iliada.

W Homerowych eposach występują wiele mówiące antropologom pojęcia, takie jak sốma stanowiąca sumę niezależnych części (the sum total of his limbs, gr. mele) $)^{8}$. Także znacznie młodsze przekazy Safony mówią o „ciele rozczłonkowanym” (body in pieces) $)^{9}$ i napięciu między frag-

3 Choć Światowa Organizacja Zdrowia nadal tak czyni: „,modele medyczne traktują niepełnosprawność jako problem dotyczący osoby (as a problem of the person), której zdrowie bezpośrednio dotyka choroba, trauma lub inne ograniczenie, wymagające indywidualnej opieki medycznej świadczonej przez profesjonalne podmioty medyczne (individual treatment by professionals). Celem terapeutycznym jest tutaj wyleczenie, poprawa lub przystosowanie jednostki do niepełnosprawności. Opieka medyczna stanowi kwestię podstawową. Z kolei polityka zdrowotna odpowiada za rozwój i reformę służby zdrowia" (Genewa 2001, s. 20).

4 Zob. J. Ablon, "The Elephant Man" as "Self" and "Other": The Psychosocial Costs of a Misdiagnosis, "Social Science and Medicine”, vol. 40, 1995, s. 1481-1489, oraz A. R. Reid-Cummingham, Anthropological Theories of Disability, "Journal of Human Behavior in the Social Environment", vol. 19, 2009, s. 99-111.

5 Zob. E. Nowak, Ustrój cielesny w doświadczeniu podmiotowym imiędzypodmiotowym: zrozumieć fenomen allotransplantacji, „Filozofia i Nauka”, vol. 5, 2017, s. 61-87.

6 Zob. Light and Darkness in Ancient Greek Myth and Religion, eds. M. Christopoulos, E. D. Karakantza, O. Levaniouk, Lanham, Boulder, Rowmann \& Littlefield Publishers, New York-Toronto 2010.

7 Zob. B. Patzek, Homer und die frühen Griechen, De Gruyter, Berlin - Boston 2017.

8 B. Snell, The Discovery of Mind: The Greek Origins of European Thought, transl. T. G. Rosenmeyer, Cambridge 1953, s. 8 (pol. Odkrycie ducha, przeł. A. Onysymow, Fundacja Aletheia, Warszawa 2009, s. 19).

9 P. DuBois, Sappho Is Burning, The Univ. of Chicago Press, Chicago-London, 1995, s. 75. 
mentem ${ }^{10}$ i całościa jak podkreśla Page Dubois. Całościowe, a z czasem także organiczne wyobrażenie ciała ukształtowało się później, na styku rozmaitych kultur rejonu Morza Śródziemnego, w odpowiedzi na rodzącą się wiarę w nieśmiertelność duszy. Zanim psyche uzyskała odrębny, niematerialny byt, a Grecy przekazali nam w swoim filozoficznym testamencie dualizm ciała i ducha, w ich kulturze - podobnie, jak w kulturach sąsiednich - panował animizm. Wszelka materia (także martwe ciało) jest ożywiona, zatem i "nagie i nadpsute ciało” godzi się złożyć w grobie, by nie rozszarpały go zwierzęta: tak czyni Antygona, która antycypuje już także rygory integralności, nienaruszalności i nieczystości (nidda) właściwe żydowskim obrzędom pogrzebowym.

Starsze od greckich świadectwa z terenów Egiptu i Babilonii dowodza, że kwitła tam hermeneutyka przeznaczenia $(f a t e)^{11}$, odczytywanego z fizjognomicznych, morfologicznych i mimicznych "znaków", zwana morfoskopią lub fizjognomiką "zodiakalną" (Zodiacal Physiognomy) ${ }^{12}$. Ciało ludzkie nosiło ślady działania sił kosmicznych lub boskich, nadające poszczególnym jego częściom i powierzchowności znamiona eschatologiczne i mesjanistyczne, ale także etniczne oraz socjologiczne, świadczące np. o tym, że przybyły do Egiptu Józef ${ }^{13}$ nie urodził się w niewoli. Morfoskopia przeniknęła do talmudycznego judaizmu, który nasycał swój dyskurs kryteriami biometrycznymi. Pozwalały one wnosić o ludzkim usposobieniu, dobrych lub złych zamiarach, a także o tożsamości ${ }^{14}$ oraz przynależności etnicznej, rodowej i politycznej. Siłą rzeczy te same kryteria pozwalały wnosić o nieprzynależności, obcości i wrogości ${ }^{15}$. Na personifikacji odpowiednich cech opiera się wiele przypowieści biblijnych ${ }^{16}$.

Względnie dobrze znany jest nieprzychylny stosunek Greków i mało przychylny stosunek Rzymian do niepełnosprawności. W miarę postępu

10 Ibidem, s. 58.

11 M. Popović, Reading the Human Body. Physiognomics and Astrology in the Dead Sea Scrolls and Hellenistic-Early Roman Period Judaism, Brill, Leiden 2005, s. 4n.

12 Ibidem, s. 211.

13 "Your are not a slave, for also your appearance reveals who you are", ibidem, s. 290.

14 Zob. A. L. A. Hogeterp, Eschatological Identities in the Damascus Document, w: Defining Identities: We, You, and the Other in the Dead Sea Scrolls, eds. F. G. Martínez, M. Popović, Brill, Leiden - Boston 2008, s. 111-130; G. W. E. Nickelsburg, Polarized Self-Identifications in the Qumran Texts, ibidem, s. 23-32; J. Jokiranta, Social Identity Approach. Identity Constructing Elements in the Psalms Pesher, ibidem, s. 85-110.

15 Zob. H. K. Harrington, Keeping Outsiders Out: Impurity at Qumran, w: Defining Identities, op. cit., s. 187-204.

16 Na temat wizerunku człowieka 'złego' zob. R. D. Moore, Personification of the Seduction of Evil: The Wiles of the Wicked Woman, "Review de Qumran”, vol. 10, no. 40 (1979-1981), s. 505-519; zob. też J. Wright Knust, Unprotected Texts. The Bible's Surprising Contradictions About Sex and Desire, HarperCollins Publishers, New York 2011. 
'ducha praw' Rzymianie nadali niepełnosprawnym pewne uprawnienia (a przynajmniej ujęli im obowiązków), ale i oni znali instytucję 'dowodu człowieczeństwa', jakiego niekiedy wymagano od osoby ze znaczną niepełnosprawnością ${ }^{17}$. Powstaje więc pytanie, jak $\mathrm{w}$ tamtym czasie odnoszono się do niepełnosprawności w kulturze żydowskiej, znanej z higienicznych rygorów. Rozważmy dwa przykłady: pierwszy dotyczy upośledzenia wzroku, a także znamion oka i jego oprawy, świadczących np. o tym, że ich posiadacz nie jest predysponowany do posług kapłańskich (zob. Księga Kapłańska). Podług źródeł talmudycznych oko stanowi „naczynie" połączone z sercem. Białko oka pochodzi od biologicznego ojca, ciemna źrenica - od matki. Do ślepoty wrodzonej przyczynia się wedle Talmudu ojciec dziecka, który spojrzał na pochwę matki ${ }^{18}$, ale może ona mieć także inne, bardziej naturalne podłoże. Pierwsza żona Jakuba, Lea, miała stracić wzrok wskutek długotrwałego płaczu. Ze starości zaniewidzieli także Izaak, Jakub i Lot. W przywołanej pracy Mansur et al. wymieniają przynajmniej dziesięć różnych remediów stosowanych w chorobach oczu, o których mowa w Talmudzie. Można więc przyjąć, że kultura żydowska od początku pielęgnowała terapeutyczne podejście do niepełnosprawności.

Jednak to nie wzrok, a mowa i słuch wydają się mieć kluczowe znaczenie $w$ judaizmie. Przybliża je XII-wieczna legenda o Golemie (hebr. גולם, bezkształtna masa, niedokończony twór) ulepionym z gliny na podobieństwo Adama, niecałkiem jednak na "obraz i podobieństwo" Stwórcy. Golem okazał się głuchoniemy i niezdarny, a przecież jakoś animalnie żywotny. Zarówno u Arystotelesa, jak i u Majmonidesa mowa i słuch znamionują rozumność. Zgodnie z takim kryterium interpretowany jest odnośny werset Księgi Rodzaju (Genesis Rabbah 2,3) mówiący o „.... tchnieniu ducha”. Idzie tu najwyraźniej o „ducha, który mówi (ruah memalela)"19. Legendę o Golemie zrewidował Gershom Scholem, wyjaśniając, że cechy ludzkie tylko potencjalnie odzwierciedlają atrybuty boskie. W słynnym poemacie przypomniał o tym Jorge Luis Borges:

(...) I tak oto stwór powieki ospale rozwarł

i ujrzał niepojęte dlań formy i kolory,

17 D. Zames Fleischer, F. Zames, Disability Rights Movement. From Charity to Confrontation, Temple University Press, Philadelphia 2001, s. 14.

18 Ślepota nie musi być przy tym dziedziczna, zob. A. M. Mansour, D. Gold, H. I. Salti, Z. M. Sbeity, The Eye in the Old Testament and Talmud, "Survey of Ophthalmology", vol. 49, 2004, no. 4, s. 448.

19 T. C. Marx, Disability in Jewish Law, Routledge, London - New York 2002, s. 22-23. Zagadnienie niepełnosprawności w judaizmie jest niezwykle złożone i wymaga oddzielnego studium, a moralna i prawna odpowiedź na nią to nie tyle aretologia, ile deontologia formułująca rygorystyczne obowiązki. 
a nad tym wszystkim zgiełk, rumory, po czym bojaźliwie poruszyć się spróbował.

(...) Kabalista, co rolę idola spełniał, wielkiego stwora przezwał Golem.

(...) Możliwe, że w pisowni była jakaś usterka albo w artykulacji Świętej Nazwy; mimo czarnoksięstwa najprzedniejszej marki nie nauczył się mówić kandydat na człowieka.

(...) Coś nienormalnego i szorstkiego było w Golemie,

(...) Rabin z czułością na niego spoglądał i z jakąśs zgrozą.

(...) Czemu dałem się nabrać na dodanie jeszcze jednego symbolu do nieskończonego ciągu? Czemu do wijącego się w wieczności czczego wątku dodałem jeszcze jedną przyczynę, skutek i cierpienie? (...)

Fragmenty Golema w przekładzie Edwarda Stachury

Oba te przykłady, tj. postrzeganie ograniczeń związanych ze wzrokiem, mową i słuchem pokazują dominację czegoś, co nazwałabym logo-echo-centryzmem i zarazem wyznacznikiem kultury „pojęcia” w odróżnieniu od wzrokocentryzmu jako wyznacznika innych, mistycznie, twórczo bądź estetycznie zorientowanych tendencji. Co ciekawe, w tradycji islamu biologiczne ograniczenia indywidualizują kondycję ludzką tak bardzo, że ta właśnie różnica staje się zasadą bardziej uniwersalną od jednego, dla wszystkich skrojonego ideału doskonałości. Zarówno w islamie, jak i w judaizmie Bóg ma swoje atrybuty, człowiek zaś - swo$\mathrm{je}^{20}$. Daje to zupełnie nowy impuls rozwojowy odnośnym antropologiom niepełnosprawności (nie mogę ich tutaj szerzej omawiać ze względu na ograniczoną objętość artykułu).

Antyczny kontekst stanowi wdzięczny przedmiot badań również w kontekście przełomu anatomicznego, kiedy to odkryto współzależność organów i ich wartość dla życia, funcjonowania organizmu i wreszcie dla morfologicznej integralności ciała. W hierarchii stosowanej

20 M. S. Bazna, T. A. Hatab, Disability in the Qur'an: The Islamic Alternative to Defining, Viewing, and Relating to Disability, "Journal of Religion, Disability and Health", vol. 9, 2008, no. 1, s. 11. Prorok miał niewidomego przyjaciela, Ibn Maktuma, któremu objawione zostały pewne wersy Koranu. Z tego względu odróżnia się tutaj ślepotę jako zjawisko fizjologiczne od niezdolności widzenia w sensie wewnętrznej naoczności, która jest dla człowieka przewodnikiem duchowym, ibidem, s. 13. 
m.in. przez Galena kluczowe znaczenie przypada organom niezbędnym dla życia, objętym kategorią hegemonikon. Status taki miało serce wraz z naczyniami wieńcowymi, płuca, wątroba i mózg. Organy zapewniające funkcjonolność organizmowi, a morfologiczną integralność ciału przebadał Galen. Ustalił on, że w całej tej topografii mózg koordynuje relacje organizmu i duchem ${ }^{21}$, co na zawsze zdefiniowało topografię naturalnej kondycji ludzkiej. Do jego ustaleń odwoływał się m.in. Avicenna, wyróżniając trzy podstawowe kategorie wadliwej budowy fizycznej: mala compositio (dysmorfia i deformacja organów), mala complexio (niezdrowy wygląd) i solutio continuitatis (wadliwa postura, w tym złamania, okaleczenia, urazy etc. $)^{22}$.

Nie jest prawdą że celebrując doświadczenie doloryczne, średniowiecze nie stroniło od badań nad integralnością i dezintegracją ciała ludzkiego. Obok archetypów starszych, jak dziwność, omen, stygmat ${ }^{23}$, narodziny z niedozwolonego związku, kara spadająca na ród (z której wywodzi się wstyd, ukrywanie, banicja niedołężnego członka rodziny) pojawiają się nowe: łaska i cud uzdrowienia, instytucjonalizacja (wieloletnie odosobnienie w "Hôtel-Dieu”, sierocińcu bądź lazarecie ufundowanym przez mecenat dworski ${ }^{24}$ ), wreszcie charytatywna aretologia miłosierdzia, litości, współczucia i altruizmu, dla wielu po dziś dzień będąca adekwatną odpowiedzią moralną na niepełnosprawność. Postawa bardziej niż afirmatywna, tj. głęboko paternalistyczna, może jednak skutkować silną asymetrią w relacjach opiekuna i podopiecznego, prowadząc do ubezwłasnowolnienia i wykluczenia tego drugiego z wielu sfer praktyki, partycypacji, interakcji ${ }^{25}$, ostatecznie nasilając negatywny

21 Galen, De usu partium, zob. J. Rocca, Galen on the Brain. Anatomical Knowledge and Physiological Speculation in the Second Century AD, Brill, Leiden - Boston 2003, s. 222n. Po wiwisekcjach Herophilusa (II n.e.) na kilkanaście stuleci zabroniono sekcji zwłok i badań anatomicznych, co zrodziło pseudonaukowe domysły, por. B. Gladigow, Anatomia sacra, w: Ancient Medicine in Its Socio-Cultural Context, eds. P. J. van der Eijk, H. F. J., Horstmanshoff, P. H. Schrijvers, vol. I-II, Brill, Amsterdam 1995; oraz Andreas Vesalius' First Public Anatomy at Bologna, 1540. An Eyewitness Report by Baldasar Heseler Together with His Notes on Matthaeus Curtius' Lectures on Anatomia, ed. R. Eriksson, Almquist and Wiksell, Uppsala 1959, s. 345-361.

22 Zob. fascynującą monografię autorstwa I. Metzler, Disability in Medieval Europe. Thinking About Phyical Impairment During the High Middle Ages, c. 1100-1400, Routledge, London - New York 2006, s. 68-69.

23 Por. R. Kieckhefer, Magic in the Middle Ages, Cambridge University Press, Cambridge 1989.

${ }_{24} \mathrm{~Np}$. zakład Quinze-Vingt dla trzystu niewidomych, którego fundatorem był św. Ludwik (król Ludwik IX), zob. Encyclopedia of Disability, volume eds. S. L. Snyder, David T. Mitchell, general ed. Gary C. Albrecht, vol. 3, Sage, New York 2006, s. 237-238.

$25 \mathrm{Tj}$. myślenia ponad kategoriami tragizmu (non-tragic) i humanitaryzmu. Afirmacja jest cechą dystynktywną dominującego dziś etosu niepełnosprawności, zob. 
wizerunek dysmorfii i dysfunkcji, wreszcie aktywny ableizm ${ }^{26}$. Niezależnie od tego bilans normatywno-instytucjonalny pomocy, jaką średniowiecze potrafiło zaoferować niepełnosprawnym, jest imponujący.

Współcześnie narracje, ikonologie oraz ikonografie niepełnosprawności mogą wyrażać zdziwienie i potrzebę zrozumienia, emocje, a także realizm w zetknięciu z ciałem w jego rozmaitych „wariacjach”, podkreśla Rosemarie Garland-Thompson. Nastawienia te pomagają wytworzyć schematy interpretacyjne, zaprowadzić równowagę emocjonalną w relacjach ciała z otoczeniem, rozwinąć rozmaite praktyki przez osoby sprawne i niepełnosprawne, wreszcie uchwycić dynamikę „ucieleśnionej jaźni" ${ }^{27}$. Ikonologie średniowieczne czerpały jednak z innych źródeł: namysłu teologicznego i zwyczajów ludowych ${ }^{28}$. Teologów nurtował m.in. dogmat zmartwychwstania ciała w kontekście tożsamości biologicznej, w tym: procesu obumierania i regeneracji tkanek ${ }^{29}$. Nieortodoksyjne rozwiązanie obmyślił Orygenes, którego zdaniem każde indywidualne ciało posiada niezmienny i tylko jemu właściwy eidos. "Obraz” ten ma być "gwarancją tożsamości zmartwychwstałego ciała", jest bo-

J. Sail, S. French, Towards the Affirmation Model of Disability, "Disability \& Society", vol. 15,2000 , no. 4 , s. 569-582.

${ }_{26} \mathrm{Z}$ biegiem średniowiecza w Europie narastała tendencja do tzw. normalizacji, ograniczająca prawa osób upośledzonych umysłowo, zob. Encyclopedia of Disability, op. cit., s. 872; w okresie późniejszym, aż do końca XIX w. w środowiskach wielkomiejskich wzmagała się tendencja do interpretacji upośledzeń fizycznych i ruchowych w terminach patologii i degeneracji. Miało to związek z koncepcjami eugenicznymi i prowadziło do ukrywania niepełnosprawności, a co za tym idzie - do zjawiska idącego pod prąd rozwoju trwającego od średniowiecza: mianowicie do deinstytucjonalizacji pomocy społecznej na rzecz niepełnosprawnych. Pierwszy etap deinstytucjonalizacji pogorszył ich położenie i kondycję, doprowadził bowiem do segregacji na tle eugenicznym i zaniedbań rehabilitacyjnych: „niepełnosprawne dzieci trzymano w komórkach lub przywiązywano do szafy, a zakłady opiekuńcze świeciły pustkami", ibidem, s. 242. Drugi etap nadal trwa; jego celem jest włączanie osób (zwł. dzieci) z niepełnosprawnościami do możliwie pełnego życia społecznego, co wymaga nowych form wsparcia socjalnego, przystosowania szkolnictwa, miejsc pracy, instytucji publicznych, etc. Wiele krajów nadal sobie z tym wyzwaniem nie radzi.

27 R. Garland-Thompson, Disability Studies: Enabling the Humnities, op. cit., s. $58-75$.

${ }^{28}$ Takich jak ten, który popychał XV-wiecznych niemieckich wieśniaków do okaleczania dzieci skazańców, a ubogich mieszczuchów - do czynienia tego samego własnym dzieciom, by lepiej zarabiały jako żebracy, zob. Encyclopedia of Disability, op. cit., s. 247. Z kolei inwalidztwo jako efekt kar cielesnych zainteresowało dopiero Michela Foucaulta w Nadzorować i karać; o inwalidztwie weteranów wojennych i zwykłych obywateli, burzącym idylliczny obraz socjalizmu w ZSRR, zob. Sarah D. Philips, There Are No Invalids in the USSR!: A Missing Soviet Chapter in the New Disability History, "Disability Studies Quarterly”, vol. 29, 2009, no. 3, bez paginacji, e-źródło, http://dsq-sds.org/article/view/936/1111 [dostęp: 19.01.2018].

${ }_{29}$ Zob. Tomasz z Akwinu, Zmartwychwstanie ciat, przeł. P. Bełch OP, Summa Teologiczna, t. XXXIII, Londyn 1962-1998. 
wiem doskonalszy od oryginału i „okryty chwałą"30. Także w świetle poglądów Akwinaty ludzie wstaną z martwych „bez żadnej naturalnej wady"31, integralni, sprawni, ani zbyt młodzi, ani zbyt starzy. Jeśli jednak podstawowym kryterium zmartwychwstania jest posiadanie duszy rozumnej, to na drodze do zmartwychwstania stawałby jej brak (choć niekoniecznie deficyt władz duchowych).

U schyłku epoki należącej do antropologii scholastycznej, ok. połowy XVII w. schematów pomocnych w objaśnianiu przypadłości psychofizycznych zacznie dostarczać antropologia filozoficzna. Ze zmiennym szczęściem: przyznając kondycji ludzkiej status metafizyczny ${ }^{32}$, nie wyswobodzi jej przecież z paulińskiej wizji natury ludzkiej jako siedliska malum physicum. Wszystkiemu winien jest „dublet empiryczno-transcendentalny, zwany człowiekiem"33, powie Foucault. Dominujący w tym dublecie duch będzie musiał wytworzyć nowe reprezentacje, by zrozumieć, afirmować i przeżywać cielesność taka, jaką jest, choć być nie powinna $\mathrm{w}$ świetle nadal ambiwalentnych ocen, zwyczajów i konwencji społecznych ${ }^{34}$.

\section{Inwalidztwo w świetle antropologii filozoficznej (Kant, Herder, Gehlen)}

W epoce, którą Kevin Stagg nazywa „proto-antropologiczną” (przełom XVI i XVII w.) po trwającym przez wiele stuleci zakazie przeprowadzania sekcji zwłok odrodziła się anatomia ${ }^{35}$. Jednocześnie pojawiła się te-

30 G. Agamben, Nagość, przeł. K. Żaboklicki, W.A.B., Warszawa 2010, s. 102-103.

31 Ibidem, s. 101. Co ciekawe, zmartwychwstanie ciała kobiecego, dla Akwinaty z natury rzeczy ",kalekiego” (co do końca XIX w. utrzymało się w nauce Kościoła), nastąpi na równi ze zmartwychwstaniem ciała męskiego.

${ }^{32}$ W rozumieniu Kantowskiej Metafizyki moralności.

33 M. Foucault, Stowa i rzeczy. Archeologia nauk humanistycznych, przeł. T. Komendant, słowo/obraz terytoria, Gdańsk 2006, s. 287.

34 D. L. Vay, The History of Orthopaedics: An Account of the Study and Practice of Orthopaedics from the Earliest Times to the Modern Era, Parthenon, Cornforth and Park Ridge 1990. Protetyka nie jest jednak wynalazkiem nowoczesności. Najstarsza, wykonaną $\mathrm{z}$ drewna protezę stopy odkryto $\mathrm{w}$ jednym ze stanowisk archeologicznych Egiptu, liczy ponad 4000 lat.

35 Zob. P. Mitchell, The Purple Island and Anatomy in Early Seventeenth Century-Literature, Philosophy, and Theology, Rosemont Publishing, Cranbury 2007. Renesans anatomii był związany z rozprzestrzeniającym się w ówczesnej Europie protestantyzmem, podkreśla Mitchell. Tytułowy poemat „The purple Island”, pl. „Szkarłatna wyspa" (in. The isle of man) autorstwa Phineasa Fletchera (1582-1650) alegorycznie opisywał topografię ludzkiego ciała, porównywanego do mikrokosmosu. Miał on później inspirować nie tylko świat medyczny, ale i filozofów, w tym Nietzschego i Foucaulta, ibidem, s. 17-19. 
ratoskopia (teratoscopy) ${ }^{36}$, objaśniająca dysmorfie i dysfunkcje fizyczne w kategoriach już nie tyle "omenu", ile biologii i medycyny ${ }^{37}$. Przykładem prace brytyjskiego lekarza Johna Bolwera, zwł. Anthropometamorphosis $^{38}$. Modernizacji ulegała semiotyka i semantyka anatomii, obejmujących także dysmorfie i dysfunkcje ciała. Nowym językiem nasiąkała także refleksja humanistyczna ${ }^{39}$, w której mieści się przednowoczesna antropologia filozoficzna, pragmatyczna, kosmopolityczna ${ }^{40}$ etc., zapoczątkowana przez Immanuela Kanta.

Kant znał pisma Plattnera (Anthropologie für Ärzte und Weltweise, 1772), poświęcone fizycznym i fizjologicznym aspektom inwalidztwa ${ }^{41}$, ale interesowały go one już wcześniej. Przyjmował, że wrodzona bądź losowo nabyta niepełnosprawność fizyczna należy do z natury niedoskonałej kondycji homo phaenomenon. Kondycja ta umożliwia realizację ideału człowieczeństwa (homo noumenon) i jego „mocy moralnej” tożsamej z moralną godnością $\mathrm{w}$ takim stopniu, w jakm indywiduum potrafi temu sprostać. Nie należy tych szans ograniczać, toteż Metafizyka moralności nakazuje szacunek dla cielesnej integralności każdego człowieka. Samobójstwo lub dobrowolne 'rozczłonkowanie’42 własnego ciała „czyni

36 K. Stagg, Representing Physical Difference: The Materiality of the Monstrous, w: Social Histories of Disability and Deformity, eds. D. M. Turner, K. Stagg, Routedge, New York 2006, s. 24.

37 W tym czasie wzbierała już pierwsza fala antropologii ewolucyjnej, której fatalną kulminację omówiłam w artykule pt. Abyście się wzmacniali i przedłużali życie na ziemi. Eschatologia doskonałości, Niddah i skandal higieny rasowej w okresie 1850-1945, „Ethics in Progress”, vol. 7, 2016, no. 1, s. 103-117, http://pressto.amu.edu.pl/index. php/eip/article/view/8101.

38 J. Bulwer, Anthropometamorphosis, Man Transform'd, or, The Artificial Changeling Historically Presented in the Mad and Cruel Gallantry, J. Hardesty, London 1650.

39 Por. J. L. Nelson, Bulwer's Speaking Hands: Deafness and Rhetoric, w: Disability Studies: Enabling the Humanities, eds. S. L. Snyder, B. J. Brueggemann, R. Garland-Thomson, Modern Language Association of America, New York 2002.

40 Niektórzy widzą w Kancie ostatniego przedstawiciela antropologii scholastycznej i zarazem kosmopolitycznej, przykładającego te same miary do wszystkich ludzi mimo ewidentnych różnic.

${ }^{41}$ Również w niechlubnym kontekście etniczno-rasowo-historiozoficznym, zob. P. Kleingeld, Kants Second Thoughts on Race, "The Philosophical Quarterly", vol. 57, 2007, no. 29, s. 574-592.

42 I. Kant, Metafizyka moralności, przeł. E. Nowak, PWN, Warszawa 2005, s. 293. Niemoralnie postępuje ten, kto „sam pozbawia się pewnych integralnych organów ciała, dokonując samookaleczenia [...] Okaleczenie własnego ciała przez pozbawienie go jakiegoś członka bądź organu podpada pod samobójstwo niezupełne - niech to będzie oddanie lub odsprzedanie komuś zęba celem wszczepienia go w dziąsło innej osoby albo też poddanie się kastracji po to, by wieść wygodny żywot śpiewaka itd. Co innego zaś, gdy jakiś organ obumrze samoistnie albo gdy trzeba go usunąć (Amputation) z powodu zagrożenia, jakie stwarza dla czyjegoś życia; podobnie, jeśli chodzi o te części ciała, które nie stanowią jego organów", ibidem, s. 295. Kant odróżnia amputację ze wskazań medycznych od tzw. apotemnofilii. Być może Kant znał przypadek króla 
[...] (doraźnie czy też dożywotnio) niezdolnym do fizycznego użycia [...] sił”, pogłębia „niemoc moralną" ${ }^{33}$ i ogranicza już z natury powolny rozwój osobistej cnoty.

Na tym jednak nie koniec. Źródłem poważniejszych problemów jest w oczach Kanta niepełnosprawność umysłowa, nie tyle okazjonalnie ograniczająca działanie vis moralis, ile bezpośrednio przyczyniająca się do czynów sprzecznych z moralnym prawodawstwem rozumu, poznawalnym dla wszystkich istot ludzkich z wyjątkiem tych, które cierpią na ograniczenie natury umysłowej, a zwłaszcza poznawczej. Kant miał trudność ze wskazaniem kryteriów pozwalających odróżnić czyn świadomie (intencjonalnie) nieodpowiedzialny i sprzeczny z obowiązkiem od czynu, którego pobudki nie leżą w „mocy moralnej” sprawcy, ograniczonej „przeszkodami pochodzenia naturalnego" (Naturhindernisse) ${ }^{44}$. Tym samym Kanta, jako 'inkompatybilistę', irytowała „naiwność” sędziów nazbyt łagodnie traktujących sprawców niepoczytalnych (np. dzieciobójczynie $)^{45}$. Jego zdaniem należnego wymiaru kary dla sprawcy czynu karygodnego (a tym bardziej imputatio iuris) nie umniejsza ograniczona poczytalność psychiczna ${ }^{46}$. „Bedauren und curiren, aber nicht bestrafen" ${ }^{\prime 4}$ to wariant nie mieszczący się w Kantowskiej antropologii,

Adolfa Fryderyka (XVIII w.), którego liczne metresy były pozbawione szeregu organów. W literaturze opisano wiele form apotemnofilii, od kastracji włoskich śpiewaków przez ekstrakcję zęba, ejakulację, wydalenie placenty i amputację profilaktyczna, por. A. Lingis, The Physiology of Art, w: The Prosthetic Impulse: From a Posthuman Present to a Biocultural Future, eds. M. Smith, J. Morra, MIT, Cambridge 2006, s. 78-85.

43 I. Kant, Metafizyka moralności, op. cit.

44 Do przeszkód naturalnych resp. przyrodniczych Kant zaliczał wyłącznie motywy bądź pobudki "patologiczne”.

45 O karze dla zabójczyni dziecka nieślubnego, pragnącej odzyskać utraconą cześć, zob. ibidem.

46 Por. P. Frieson, Kant on Mental Disorder. Part 2: Philosophical Implications of Kant's Account, „History of Psychiatry”, vol. 20, 2009, no. 3, s. 290-310. Co ciekawe, we wczesnej rozprawie pt. Versuch über die Krankheiten des Kopfes (1764) Kant rozróżnił stadia ograniczenia umysłowego, zob. I. Kant, Vorkritische Schriften 1757-1777, AkademieAusgabe, Bd. II, Königlich Preußische Akademie der Wissenschaften, Georg Reimer Verlag, Berlin 1905. Na s. 259 czytamy: „mając wybierać między głupotą i perfidią (zwischen Dummheit und Schelmerei) nikt się łatwo nie przyzna do tej pierwszej...", ale sprytowi winna towarzyszyć uczciwość, tłumaczy Kant. Za lekarzy umysłu uważał logików (die Ärzte... die sich Logiker nennen), ibidem, s. 260. W tej samej rozprawce pojawia się słynne porównanie ludzkiej głowy do bębenka, który dźwięczy tym donośniej, im bardziej w nim pusto. W zamyśle autora rozprawka miała być odpowiedzią na wizje pewnego fanatyka religijnego o polskich korzeniach, który zawitał w $1963 \mathrm{r}$. do Królewca. Kant odniósł się do tego incydentu także w rozprawce pt. Marzenia jasnowidza, datowanej na okres późniejszy.

47 I. Kant, Antropologia w ujęciu pragmatycznym, przeł. D. Sosnowska, E. Drzazgowska, Wydawnictwo IFiS PAN, Warszawa 2005. 
a tym bardziej teorii prawa. Dopiero kilka dekad później zaczęto badać wpływ "temperamentów" na poczytalność ${ }^{48}$.

Znacznie lepszego zdania o organicznej i duchowej naturze człowieka jako „całości" 49 , a także jego habitusie moralnym był oponent Kanta, Johann Gottfried Herder. Również on dostrzegał, że ludzkość nie może już polegać na instynktach ${ }^{50}$, ale nie rozwinęła jeszcze dostatecznie zdolności umysłowych. Sto lat później obserwacja ta podsunie Arnoldowi Gehlenowi myśl o antropologicznym „kryzysie” ludzkości. Ponieważ dla Herdera jednym z podstawowych kryteriów antropologicznych były ludzkie zdolności językowe, interesowało go słabo wówczas zbadane upośledzenie mowy i słuchu: „przykład głuchoniemych od urodzenia wykazuje, w jak małym stopniu człowiek pozbawiony mowy, choćby żył wśród ludzi, zdolny jest do idei rozumu i w jak zwierzęcej dzikości grzęzną jego popędy. Naśladuje to, co spostrzega jego oko, dobro i zło, naśladuje gorzej niż małpa, gdyż brak mu wewnętrznego kryterium rozróżnienia" ${ }^{\prime 1}$. Jest to pogląd o tyle trafny, że u człowieka organizacja aparatu zmysłowego jest ściśle sprzężona z umysłem, z czego Herder zdawał sobie dobrze sprawę. Mimo, że rola wzroku i synestezji w procesach poznawczych nie była jeszcze wówczas należycie zbadana, a związków między rozumieniem znaczeń ${ }^{52}$, słyszeniem i mową ledwie się domyślano, Herder intuicyjnie odkrył synestezję, gdy analizował rozwój manualnych zdolności człowieka. Swobodne dzięki pionowej postawie ciała, zręczne i pełne wyczucia dłonie, a także zdolność posługiwania się precyzyjnymi narzędziami nieustannie inspirują ludzki umysł (die neuen klaren Ideen), podkreśla Herder. Helwecjusz miał rację powiada autor Myśli... - że ręka to wspaniały narząd ludzkiego rozumu, a subtelny zmysł dotyku rozlewa się na całą powierzchnię ciała. Gdy jest ono bezwładne (verstümmelt), palce stóp potrafią czynić rzeczy, jakich nie powstydziłyby się dłonie artysty. Dzięki specjalnej strukturze mięśni niepozorny paluch i mały palec okazują się niezawodnymi podporami, gdy człowiek stoi, idzie i chwyta przedmioty, wykonując rozmaite polecenia swego "ducha".

48 Zob. M. Bergengruen, Das neue Recht und der neue Körper. Wagners Kindermörderin zwischen Anthropologie und Rechtstheorie, w: M. Bergengruen, R. Borgards, J. F. Lehmann (Mithg.), Die grenzen des Menschen. Anthropologie und Ästhetik um 1800, Verlag Königshausen \& Neumann, Würzburg 2001, s. 37-48.

${ }_{49}$ J. G. Herder, Myśli o filozofii dziejów, przeł. J. Gałecki, t. 1, PWN, Warszawa 1962, s. 143.

50 Ibidem, s. 162.

51 Ibidem, s. 157.

52 Zob. C. F. Goodey, A History of Intelligence and ,Intellectual Disability'. The Shaping of Psychology in Early Modern Europe, Ashgate, Burlington 2011, s. 334. 
Jako naturalista o zamiłowaniach metafizycznych, Herder potrafił docenić znaczenie organów nieodwracalnie uszkodzonych i pozornie bezużytecznych:

bo jeśli jakiś organ staje się nieproporcjonalny $\mathrm{w}$ stosunku do innych i wskutek tego nieużyteczny w sferze zwykłego życia ziemskiego, [...] wewnętrzna, niestrudzona siła tego organu kieruje się ku innym stronom wszechświata i odbiera być może wrażenia, do jakich organizm o niezakłóconej proporcjonalności nie był zdolny i jakich nigdy nie potrzebo$\mathrm{wat}^{53}$.

W obszernych rozważaniach etnograficznych nie pominął Herder kulturowo relatywnego postrzegania deformacji fizycznych. Przywołał m.in. wykonywaną w XVI-wiecznych Chinach plastykę powiek i uszu, krytykując przy tym kompleks ciała wyrażający się $\mathrm{w}$ „,sztucznych zabiegach”, zwłaszcza w „nienaturalnym ściskaniu stóp" ${ }^{54}$, które wpędza kobiety w dożywotnie inwalidztwo i cierpienie. Rozmaitym kulturom zarzucał Herder tuszowanie deformacji o podłożu dziedzicznym: „podstawą tych anomalii musiała być jakaś pierwotna niekształtność ciała, a do jej usunięcia posłużono się później jakimś barbarzyńskim kunsztem" ${ }^{\prime 5}$, domniemywał. Jego refleksje świadczą nie tyle o białym, oświeconym suprematyzmie ${ }^{56}$, ile o afirmacji dla „najbardziej zróżnicowanej i zawsze odmiennej postaci ludzkiej” 57 tudzież jej twórczyni, tj. „matki-przyrody, która umie wynagradzać nawet, gdy odbiera" ${ }^{58}$.

Gdyby ta sama, kompensująca reguła zadziałała w kulturze jako nowym (względem naturalnego) środowisku życia ludzkości ${ }^{59}$, poczucie własnych braków i ułomności, wyrażonych w pojęciu Mängelwesen (przypisywanym Herderowi, eksplorowanym jednak dopiero przez Gehlena) w obliczu wyzwań kulturowo-społecznych nie byłoby tak silne $^{60}$. 'Wybrakowanie' nie jest jednak cechą negatywną; przeciwnie,

53 J. G. Herder, Myśli..., s. 228. Refleksja ta przywodzi na myśl „ciało chwalebne”, oddzielone od swoich funkcji fizjologicznych i przeniesione do sfery "kultu ad maiorem Dei gloriam", G. Agamben, Nagość, op. cit., s. 110-102.

54 J. G. Herder, Myśli..., s. 244-245.

55 Ibidem, s. 247.

56 „Czarny kolor Murzynów nie jest dziwniejszy niż biały...", ibidem, s. 260. Człowiek „pozostaje w związku ze wszystkimi żywiołami przyrody [...] jest nieskończoną harmonią różnorodności, żywą jaźnią", ibidem, s. 283.

57 Ibidem, s. 280.

58 Ibidem, s. 264.

59 „Literacka, filozoficzna, moralna tematyka obłędu biegnie innym torem” M. Foucault, Historia szaleństwa w dobie klasycyzmu, przeł. H. Kęszycka, PIW, Warszawa 1987, s. 33.

${ }^{60}$ Zob. Impairment and Disability. Law and Ethic in the Beginning and End of Life, eds. S. A. M. McLean, L. Williamson, Routledge, New York 2007. 
zawiera potencjał rozwojowy, w tym plastyczność (Plastizität) ludzkich predyspozycji, objawiającą się m.in. w zmyśle technicznym, pomysłowości i języku, który uwalnia od zagrożeń i odciąża (Entlastung) od naporu rzeczy, jak wyrazi to później Arnold Gehlen ${ }^{61}$, stwarzając przestrzeń swobodnego myślenia. Ulgą à rebours (Entlastung) nazwałabym przybliżenie człowieka znajdującego się w potrzebie praktycznej, jaką stanowi niepełnosprawność fizyczna, z powrotem do świata rzeczy za pośrednictwem narzędzi zastępujących osłabione lub nieczynne narządy.

W osobie Gehlena antropologia Herdera znalazła kontynuatora ${ }^{62}$ : „Będę ją rozwijał, odwołując się do współczesnej nauki”63, deklaruje autor dzieła Der Mensch. Seine Natur und seine Stellung in der Welt. W ciele, twierdzi Gehlen - całkiem inaczej aniżeli w organizmie - motoryka jednych morfemów może być niezależna od motoryki innych. Jest to ważne nie tylko w kontekście „topografii ciała” ${ }^{64}$, lecz także w kontekście uczenia się, adaptacji do nowych warunków i koordynacji aktów mentalnych z fizycznymi. Zjawisko automatycznych czynności „,ideomotorycznych” opisał Gehlen z myślą o uczeniu się i doskonaleniu kunsztu zawodowego aż do mistrzostwa, ale można je z powodzeniem odnieść do osób niepełnosprawnych, które uczą się koordynować swą fizyczność z umysłem i posługiwać urządzeniami technicznymi, takimi, jak protezy - zwłaszcza współczesne, bioniczne, sterowane mocą umysłu. Gehlen opisał owe czynności na przykładzie muzyka, który wykonując swoją partyturę, wsłuchuje się $\mathrm{w}$ brzmienie instrumentów obsługiwanych przez pozostałych członków orkiestry, na brzmienie własnego zważając w trybie 'tacit'. Koordynacja ideomotoryczna jest możliwa dzięki temu, że ludzka ręka, wzrok, słuch i inne organy osobno i niezależnie od siebie wykonują inteligentne czynności, a zarazem czynią to w sposób synchroniczny. Powinowactwo między myślą Gehlena i myślą Herdera jest tutaj uderzające: synchronizacja ludzkiego geniuszu ${ }^{65}$, narządów należących do 'animalnej' natury człowieka i narzędzi należących do rzeczywistości przedmiotowej odznacza się tak wysokim potencjałem twórczym, performatywnym, wreszcie interaktywnym, że należy w niej widzieć speł-

${ }_{61}$ Zob. A. Gehlen, Der Mensch. Seine Natur und Seine Stellung in der Welt, Aula Verlag, Wiesbaden 1986.

${ }^{62}$ W szczególności bionika i cybernetyka, zob. B. Gleeson, Can Technology Overcome the Disabling City?, w: Mind and Body Spaces. Geographies of Illness, Impairment and Disability, eds. R. Butler, H. Paar, Routledge, London 1999, s. 98. Jednak aż do II wojny światowej ludność (zwł. brytyjska) miała traumatyczne doświadczenia z protetyka, zob. A. Borsay, Disciplining Disabled Bodies: The Development of Orthopaedic Medicine in Britain 1800-1939, w: Social Histories of Disability and Deformity, op. cit., s. 97-117.

63 A. Gehlen, Der Mensch, s. 84.

64 Ibidem, s. 138-139.

65 Tzw. Denktechniken, ibidem, zob. także, s. 83. 
nienie Herderowskiego marzenia o holistycznym rozwoju człowieka, pozwalającym mu budować świat własny, nieoderwany przecież od naturalnego kosmosu życia. Rozwój ten dowodzi, że utracone instynkty może z powodzeniem rekompensować inteligencja wspomagana przez technikę. Człowiek rozwija technikę z potrzeby samorozwoju, samorozwój zaś pozwala przezwyciężyć kryzys związany początkowo z brakiem odrębnej niszy ekologicznej i pierwotną nieokreślonością (motyw nietzscheański). Zadomowienie następuje stopniowo, przybierając wymiar kulturowy, instytucjonalny, a także techniczny: technika (i także polityka) powinna jednak pozostać w gestii człowieka, a nie na odwrót. Przypominają o tym współcześni Gehlenowi technokonserwatywni metafizycy o antropologicznych inklinacjach: Martin Heidegger i Hans Jonas $^{66}$, ostrzegając przed nihilizmem, jakim grozi panowanie techniki nad człowiekiem $^{67}$. Jednakże gdy technika służy człowiekowi, uwalniając go od niemocy, o nihilizmie nie może być mowy.

\section{Od starego do nowego paradygmatu niepełnosprawności: postconventional turn}

Poniekąd w duchu Gehlenowskiego instytucjonalizmu utrzymana będzie ostatnia część moich rozważań. Zaryzykuję tezę, że normatywne sytuowanie niepełnosprawności w XX w. odziedziczyło ambiwalencję z okresu scholastyki. Scholastyczna antropologia i aretologia utrwaliły humanitarna, patetyczno-altruistyczną odpowiedź społeczeństwa na szereg ludzkich 'niesprawności', widząc w nich deficyt, źródło cierpień i obciążenie dla innych. Dwudziesty wiek przyniósł także nowe zjawisko: laicyzację, która nie ma czym zastąpić scholastycznego schematu uwznioślenia doczesnej kondycji człowieka przez przyszłe zbawienie (a także odkupienie win, zakładane w schemacie kary za grzechy rodu, w którym na świat przychodzi dotknięte kalectwem potomstwo). Scholastycznemu miłosierdziu w obliczu tej sytuacji towarzyszyło ciche zrozumienie, rezygnacja, bierne współcierpienie: którz mierzyłby się z przeznaczeniem? Inaczej w świecie greckim, gdzie tragiczne przez swoją bezcelowość cierpienie budziło uczucia katharktyczne, oczyszczające

66 Por. M. Heidegger, Der Satz der Identität, wykład wygłoszony 27.06.1957 z okazji 500-lecia Uniwersytetu we Freiburgu, Neske, Stuttgart 1997 (audiobook); zob. także H. Jonas, Philosophie des Lebens und die Ethik der Lebenswissenschaften. KGA, Bd. I/1, Hg. von H. Gronke, Rombach Verlag, Freiburg-Breisgau-Berlin-Wien 2010, s. 319-333; wreszcie G. Danzer, Wer sind wir? Anthropologie im 20. Jahrhundert. Ideen und Theorien für die Formel des Menschen, Springer, Heidelberg - Berlin - New York 2011.

67 Zob. E. Nowak, R. F. Tibaldeo, Organizm $i$ wolność: filozofia życia $i$ etyka nauk o życiu, „Filozofia i Nauka”, nr 5, 2017, s. 29-48. 
i wzmacniające. Spadkobiercy dziedzictwa scholastycznego mogą więc odczuwać moralny dyskomfort na wieść, że domniemany 'nieszczęśnik' stroni od litości, unika miłosierdzia i współczucia, że paternalistyczna opieka prowadzi do ubezwłasnowolnienia, marginalizacji i wykluczenia, i że wykluczony z tego świata podopieczny nieskory jest do tego, by wybiegać „świadomością nieszczęśliwą" w jakieś „Jenseits”, jak ująłby to Hegel. Godniejsze i bardziej pokrzepiające byłoby dlań życie wśród 'rycerzy' i 'lekarzy' (Ritter und Arzt), dopowiada Nietzsche. Choć to „niewczesne" przesłanie autora Zaratustry nie zyskało popularności, co do jego trafności utwierdza mnie Maurice Merleau-Ponty, gdy powiada, że indywiduum „zaangażowane w pewien fizyczny i międzyludzki świat nadal wytęża siły, odnosząc się do swojego świata wbrew słabościom i amputacjom, i które właśnie dlatego de iure ich nie uznaje"68.

Nie znajdziemy jednak u Merleau-Ponty'ego wystarczająco silnej afirmacji dla niepełnosprawności, choć poświęcił jej sporo uwagi. W duchu niepowetowanej straty rozważa ten aspekt jego myśli Małgorzata Kowalska, podkreślając, że „każdy ubytek mej cielesności to bezpowrotnie zerwany kontakt ze światem"69. Jednak antropologia przełomu XX i XXI w. otwiera drogę ku nowemu: aprecjacji i afirmacji ciała w jego dotąd deprecjonowanych perypetiach ${ }^{70}$. Również Fenomenologia percepcji zawiera akapity o takim przewartościowującym potencjale: „nasze ciało daje się porównać do dzieła sztuki. Jest węzłem żywych znaczeń, a nie prawem rządzącym pewną liczbą wspólnie zmieniających się członów"71, powiada Merleau-Ponty. Droga do postscholastycznego przełomu normatywnego wokół niepełnosprawności jest więc otwarta, a scholastyczny paradygmat - podkopany.

Potrzeba jednak wiele wysiłku, zwłaszcza ze strony antropologii, etyki i nauk prawnych, by przełom dokonał się w pełni. Przyczyniają się do niego badania podejmowane przez takich specjalistów, jak Doron Dorfman. Przeanalizował on polisemię określenia „ślepa sprawiedliwość" w kontekście etosu sędziowskiego ${ }^{72}$ pod pretekstem zaprzysiężenia Richarda Bernsteina na stanowisko sędziego Sądu Najwyższego w Stanie Michigan (2014). Akt ten odbił się echem w świecie ze względu na to, że sędzia Bernstein jest pozbawiony wzroku. Warto przyjrzeć się

68 M. Merleau-Ponty, Fenomenologia percepcji, przeł. M. Kowalska, J. Migasiński, Fundacja Aletheia, Warszawa 2001, s. 99-100.

69 M. Kowalska, Relacja cielesność - rzeczywistość jako rodzaj doświadczenia w filozofii Maurice'a Merleau-Ponty'ego i jego odniesienie do widzenia obrazu malarskiego, "Humaniora", t. 1(5), 2014, s. 51.

70 Zob. M. Shildrick, Why Should Our Body End at the Skin? Embodiment, Boundaries, and Somatechnics, "Hypatia”, vol. 30(1), 2015, s. 14.

71 M. Merleau-Ponty, Fenomenologia percepcji, op. cit., s. 172.

72 J. Gershman, Richard Bernstein Brings ,Blind Justice' to Michigan's Highest Court, „The Wall Street Journal”, New York, 29 December 2014. 
zasadności tej tradycji, pielęgnowanej m.in. w USA i Wielkiej Brytanii ${ }^{73}$. Otóż personifikacje sprawiedliwości można prześledzić w przekazach wielu kultur, w tym: staroegipskiej, greckiej, rzymskiej i biblijnej. Najsilniej utrwalone jest $\mathrm{w}$ nich przedstawienie wyprostowanej postaci kobiecej, odzianej w antyczną togę i opaskę zasłaniającą oczy (niekiedy prześwitującą $\left.{ }^{74}\right)$, dzierżącej wagę i miecz. Dorfman wydobywa archetypiczne znaczenia przypisywane ślepocie, zestawiając je z historycznie dominującą narracją kalectwa, ułomności i niedołęstwa. Kojarząc ślepotę $\mathrm{z}$ „niepełnosprawnością, bezradnością lub karą za grzechy i występek”, zapomnieliśmy - powiada badacz - że

towarzyszyła ona niegdyś wysoce pozytywnym przymiotom i cnotom o pochodzeniu boskim (positive virtues of divine spirit), tj. nadzwyczajnej mądrości, przezorności (clairvoyance), a także czystemu i bezstronnemu osądowi (and fair and untainted judgment). Ta sama zdolność zatrważała i odstręczała (awe and disgust) [...] kojarząc się z obłędem [...] właśnie to nazywam paradoksem ślepej sprawiedliwości ${ }^{75}$.

Dorfman przywołuje też satyrę pt. Okręt błaznów $w^{76}$, której autorem jest Sebastian Brant, średniowieczny doktor prawa. Tytułowy okręt zmierza do raju dla obłąkanych zwanego Narragonią. Na jednej z rycin zdobiących oryginalne wydanie satyry widnieje błazen, który zasłania oczy kobiecie z mieczem, uniemożliwiając jej użycie tegoż miecza $\mathrm{w}$ akcie sprawiedliwości, tłumaczy Dorfman. Pasażerowie okrętu reprezentują wszystkie klasy ówczesnego społeczeństwa. Czytelna jest więc symbolika satyry Branta, uwydatniająca znaczenie wzroku, widzenia, jasności, poznania prawdy i formułowania sądu opartego na niej i tylko na niej. Metaforyka ta (obejmująca także światło, np. w myśli św. Jana od Krzyża), przewija się w filozofii idealistycznej od Platona po Kanta i Fichtego. Właśnie ona wyznacza podstawy etosu sędziowskiego: wszak podstawowym obowiązkiem sędziego jest wydawanie bezstronnych i obiektywnych werdyktów ${ }^{77}$ na podstawie wglądu w powierzone mu kwestie.

73 D. Dorfman, The Blind Justice Paradox: Judges with Visual Impairments and the Disability Metaphor, "Cambridge Journal of International and Comparative Law”, vol. 5, 2016, no. 2, s. 275-276.

${ }^{74}$ Dorfman opisuje też personifikacje sprawiedliwości pozbawione opasek i obdarzone wzrokiem.

75 Ibidem, s. 277.

76 S. Brant, Okręt błaznów, przeł. A. Lam, Wydawnictwo Akademii Humanistycznej im. A. Gieysztora, Pułtusk 2010. Oryginał zdobiły reprodukcje drzeworytów Albrechta Dürera.

77 D. Dorfman, The Blind Justice Paradox, op. cit., s. 284. 
Wglądu tego dokonuje on „własnymi oczyma"78, a ponadto - rozstrzyga je mocą własnego, niezależnego osądu, jak podnosi Aharon Barak.

Przywołana wyżej, postkonwencjonalna interpretacja ślepoty stanowi przyczynek do dalszej postkonwencjonalizacji niepełnosprawności jako takiej. Jest ona potrzebna, ponieważ unormowania dotyczące tej sfery nie spełniają kryteriów etycznych właściwych dojrzałemu społeczeństwu demokratycznemu ${ }^{79}$. Potrzeba nowych narracji (według Shildrick „antyheroicznych"), by gruntownie zrewidować kryteria normalności, patologii, degeneracji etc. ${ }^{80}$, negujące i wykluczające niepełnosprawność tam, gdzie w niezwykłym zróżnicowaniu jest dla niej nie po prostu miejsce, lecz przede wszystkim przestrzeń do działania, doświadczania, partycypacji, interakcji i kooperacji. Wymaga to porzucenia zadawnionych, uogólnionych i obiektywnych perspektyw, przeświadczeń i projekcji, jak podkreślają Margrit Shildrick i Roxanne Mykitiuk w pracy pt. Ethics of the Body, czyli najpierw: deregulacji, a następnie przyjęcia perspektywy samych zainteresowanych za punkt wyjścia dla nowych, postkonwencjonalnych regulacji ${ }^{81}$ : „My 'wiemy', że posiadanie tylko jednej ręki w świecie sznurowadeł oznacza niepełnosprawność, ale możemy wyobrazić sobie świat trójręczny, w którym posiadanie dwóch rąk też będzie oznaczać niepełnosprawność" ${ }^{\prime \prime 2}$.

\section{Bibliografia}

Ablon J., "The Elephant Man" as "Self" and "Other": The Psychosocial Costs of a Misdiagnosis, „Social Science and Medicine”, vol. 40, 1995, s. 1481-1489.

78 A. Barak, The Judge in a Democracy, Princeton Univeristy Press, Princeton 2006, s. $104-105$.

79 Z drugiej strony to właśnie ono - intensywniej niż inne kultury społeczne polegające na swoich zwyczajach i tradycjach - działa na rzecz prawodawstwa socjalnego. O XX-wiecznych źródłach prawa do rehabilitacji dla osób trwale niepełnosprawnych, weteranów wojennych etc. i korespondującym z nim obowiązku społeczeństwa wobec jednostki (redemption of the disabled a social obligation, the nation's duty toward the individual) zob. G. Harris, The Redemption of the Disabled: A Study of Programmes of Rehabilitation for the Disabled of War and of Industry, D. Appleton Company, New York 1919, s. 3, 39n.

80 Ethics of the Body. Postconventional Challenges, MIT Press, Cambridge 2005. Świat 'trójręczny' jest możliwy, skoro w tym kierunku zmierzają eksperymenty z urządzeniami bionicznymi.

81 Podmiotowość prawna osób niepełnosprawnych musi mieć oparcie w głosie zainteresowanych (voice their opinions) i ogólnospołecznych postulatach etycznych, zob. D. Dorfman, Re-Claiming Disability: Identity, Procedural Justice, and the Disability Determination Process, "Law \& Social Inquiry", 2016, s. 195-231.

82 J. L. Scully, Admitting All Variations? Postmodernism and Genetic Normality, w: Ethics of the Body, op. cit., s. 55. 
Agamben G., Nagość, przeł. K. Żaboklicki, W.A.B., Warszawa 2010.

Barak A., The Judge in a Democracy, Princeton University Press, Princeton 2006.

Bazna M. S., Hatab T. A., Disability in the Qur'an: The Islamic Alternative to Defining, Viewing and Relating to Disability, "Journal of Religion, Disability and Health", vol. 9, 2008, no. 1, s. 5-27.

Bergengruen M., Das neue Recht und der neue Körper. Wagners Kindermörderin zwischen Anthropologie und Rechtstheorie, w: Die grenzen des Menschen. Anthropologie und Ästhetik um 1800, Mithg. M. Bergengruen, R. Borgards, J. F. Lehmann, Verlag Königshausen \& Neumann, Würzburg 2001, s. 37-48.

Borsay A., Disciplining Disabled Bodies: The Development of Orthopaedic Medicine in Britain 1800-1939, w: Social Histories of Disability and Deformity, op. cit., s. 97-117.

Bulwer J., Anthropometamorphosis, Man Transform'd, or, The Artificial Changeling Historically Presented in the Mad and Cruel Gallantry, J. Hardesty, London 1650.

Brant S., Okręt błaznów, przeł. A. Lam, Wydawnictwo Akademii Humanistycznej im. A. Gieysztora, Pułtusk 2010.

Light and Darkness in Ancient Greek Myth and Religion, eds. M. Christopoulos, E. D. Karakantza, O. Levaniouk, Lanham, Boulder, Rowmann \& Littlefield Publishers, New York-Toronto 2010.

Danzer G., Wer sind wir? Anthropologie im 20. Jahrhundert. Ideen und Theorien für die Formel des Menschen, Springer, Heidelberg - Berlin - New York 2011.

Dorfman D., The Blind Justice Paradox: Judges with Visual Impairments and the Disability Metaphor, „Cambridge Journal of International and Comparative Law", vol. 5, 2016, no. 2, s. 272-305.

Dorfman D., Re-Claiming Disability: Identity, Procedural Justice, and the Disability Determination Process, w: „Law \& Social Inquiry”, vol. 42, 2017, no. 1, s. 195-231.

DuBois P., Sappho Is Burning, Chicago and London, The Univ. of Chicago Press 1995.

Eriksson R. (ed.), Andreas Vesalius' First Public Anatomy at Bologna, 1540. An Eyewitness Report by Baldasar Heseler Together with His Notes on Matthaeus Curtius' Lectures on Anatomia, Almquist and Wiksell, Uppsala 1959, s. 345-361.

Foucault M., Historia szaleństwa w dobie klasycyzmu, przeł. H. Kęszycka, PIW, Warszawa 1987.

Frieson P., Kant on Mental Disorder. Part 2: Philosophical Implications of Kant's Account, "History of Psychiatry”, vol. 20, 2009, no. 3, s. 290-310.

Gehlen A., Der Mensch. Seine Natur und Seine Stellung in der Welt, Aula Verlag, Wiesbaden 1986.

Galen, De usu partium, za: Rocca J., Galen on the Brain. Anatomical Knowledge and Physiological Speculation in the Second Century AD, Brill, Leiden-Boston 2003. 
Gleeson B., Can Technology Overcome the Disabling City?, w: Mind and Body Spaces. Geographies of Illness, Impairment and Disability, eds. R. Butler, H. Paar, Routledge, London 1999, s. 97-117.

Gershman J., Richard Bernstein Brings ,Blind Justice' to Michigan's Highest Court, ",The Wall Street Journal”, New York, 29 December 2014.

Gladigow B., Anatomia sacra, w: Ancient Medicine in Its Socio-Cultural Context, eds. P. J. van der Eijk, H. F. J., Horstmanshoff, P. H. Schrijvers, vol. I-II, Brill, Amsterdam 1995.

Harrington H. K., Keeping Outsiders Out: Impurity at Qumran, w: Defining Identities, We, You, and the Other in the Dead Sea Scrolls, eds. F. García Martinez, M. Popović, Brill, Leiden - Boston 2008, s. 187-204.

Harris G., The Redemption of the Disabled: A Study of Programmes of Rehabilitation for the Disabled of War and of Industry, D. Appleton Company, New York 1919.

Herder J. G., Myśli o filozofii dziejów, przeł. J. Gałecki, t. 1, PWN, Warszawa 1962.

Hogeterp A. L. A., Eschatological Identities in he Damascus Document, w: Defining Identities: We, You, and the Other in the Dead Sea Scrolls, eds. F. García Martínez, M. Popović, Brill, Leiden - Boston 2008, s. 111-130.

Jokiranta J., Social Identity Approach. Identity Constructing Elements in the Psalms Pesher, w:, Defining Identities: We, You, and the Other in the Dead Sea Scrolls, eds. F. García Martínez, M. Popović, Brill, Leiden - Boston 2008, s. $85-110$.

Jonas H., Philosophie des Lebens und die Ethik der Lebenswissenschaften. KGA, Bd. I/1. Hg. von H. Gronke. Freiburg/Breisgau - Berlin - Wien: Rombach Verlag 2010, s. 319-333.

Kant I., Antropologia w ujęciu pragmatycznym, przeł. D. Sosnowska, E. Drzazgowska, Warszawa: Wydawnictwo IFiS PAN 2005.

Kieckhefer R., Magic in the Middle Ages, Cambridge: Cambridge University Press 1989.

Kleingeld P., Kants Second Thoughts on Race, "The Philosophical Quarterly", vol. 57, 2007, no. 29, s. 574-592.

Knust J. W., Unprotected Texts. The Bible's Surprising Contradictions About Sex and Desire, HarperCollins Publishers, New York 2011.

Kowalska M., Relacja cielesność - rzeczywistość jako rodzaj doświadczenia w filozofii Maurice'a Merleau-Ponty'ego i jego odniesienie do widzenia obrazu malarskiego, „Humaniora”, t. 1(5), 2014.

Lingis A., The Physiology of Art, w: The Prosthetic Impulse: From a Posthuman Present to a Biocultural Future, eds. M. Smith, J. Morra, MIT, Cambridge, MA 2006, s. 78-85.

Mansour A. M., Gold D., Salti H. I., Sbeity Z. M., The Eye in the Old Testament and Talmud, "Survey of Ophthalmology”, vol. 49, 2004, no. 4, s. 446-453.

Marx T. C., Disability in Jewish Law, Routledge, London-New York 2002.

McLean S. A. M., Williamson L. (eds.), Impairment and Disability. Law and Ethic in the Beginning and End of Life, Routledge, New York 2007. 
Merleau-Ponty M., Fenomenologia percepcji, przeł. M. Kowalska, J. Migasiński, Fundacja Aletheia, Warszawa 2001.

Metzler I., Disability in Medieval Europe. Thinking About Phyical Impairment During the High Middle Ages, c. 1100-1400, Routledge, London-New York 2006.

Mitchell P., The Purple Island and Anatomy in Early Seventeenth Century-Literature, Philosophy, and Theology, Rosemont Publishing, Cranbury 2007.

Nickelsburg G. W. E., Polarized Self-Identifications in the Qumran Texts, w: F. García Martínez, M. Popović (eds.), Defining Identities: We, You, and the Other in the Dead Sea Scrolls, Brill, Leiden-Boston 2008, s. 23-32.

Nowak E., Ustrój cielesny w doświadczeniu podmiotowym $i$ międzypodmiotowym: zrozumieć fenomen allotransplantacji, „Filozofia i Nauka”, t. 5, 2017, s. $61-87$.

Nowak E., Tibaldeo R. F., Organizm i wolność: filozofia życia i etyka nauk o życiu, „Filozofia i Nauka”, t. 5, 2017, s. 29-48.

Nowak E., Abyście się wzmacniali i przedłużali życie na ziemi. Eschatologia doskonałości, Niddah i skandal higieny rasowej w okresie 1850-1945, „Ethics in Progress", vol. 7, 2016, no. 1, s. 103-117, http://pressto.amu.edu.pl/ index.php/eip/article/view/8101.

Patzek B., Homer und die frühen Griechen, De Gruyter, Berlin - Boston 2017.

Philips S. D., There Are No Invalids in the USSR!: A Missing Soviet Chapter in the New Disability History, "Disability Studies Quarterly”, vol. 29, 2009, no. 3, bez paginacji, e-źródło, http://dsq-sds.org/article/view/936/1111 [dostęp: 19.01.2017].

Popović M., Reading the Human Body. Physiognomics and Astrology in the Dead Sea Scrolls and Hellenistic-Early Roman Period Judaism, Brill, Leiden 2005.

Reid-Cummingham A. R., Anthropological Theories of Disability, "Journal of Human Behavior in the Social Environment", vol. 19, 2009, s. 99-111.

Rocca J., Galen on the Brain. Anatomical Knowledge and Physiological Speculation in the Second Century AD, Brill, Leiden - Boston 2003.

Sail J., French S., Towards the Affirmation Model of Disability, „Disability \& Society", vol. 15, 2000, no. 4, s. 569-582.

Shildrick M., Why Should Our Body End at the Skin? Embodiment, Boundaries, and Somatechnics, "Hypatia”, vol. 30(1), 2015, s. 13-28.

Shildrick M., Mykitiuk R. (Eds), Ethics of the Body. Postconventional Challenges, MIT Press, Cambridge 2005.

Snell B., The Discovery of Mind: The Greek Origins of European Thought, transl. T. G. Rosenmeyer, Cambridge, Mass. 1953 (pol. Odkrycie ducha, przeł. A. Onysymow, Fundacja Aletheia, Warszawa 2009).

Snyder S. L., Mitchell D. T. (Volume Editors), Gary C. Albrecht (General Editor), Encyclopedia of Disability, vol. 3, Sage, New York 2006.

Snyder S. L., Brueggemann B. J., Garland-Thomson R. (eds.), Disability Studies: Enabling the Humanities, Modern Language Association of America, New York 2002.

Turner D. M., Stagg K. (Eds), Social Histories of Disability and Deformity, Routedge, New York 2006. 
Vay D. L., The History of Orthopaedics: An Account of the Study and Practice of Orthopaedics from the Earliest Times to the Modern Era, Parthenon, Cornforth and Park Ridge 1990.

Zames F. D., Zames F., Disability Rights Movement. From Charity to Confrontation, Temple University Press, Philadelphia 2001.

\section{Streszczenie}

\section{Antropologia niepełnosprawności: narodziny, schyłek i odrodzenie paradygmatu}

Artykuł rekonstruuje przede wszystkim główne etapy refleksji antropologicznej na temat niepełnosprawności człowieka. Każdy etap wykazuje pewne mocne strony, ale jednocześnie ograniczenia, ponieważ - zgodnie z tezą autora - ludzkość wciąż nie osiągnęła odpowiedniej jakości współistnienia osób niepełnosprawnych i osób aktywnych. Po drugie, w artykule przeanalizowano współczesne antropologie filozoficzne, które mogłyby wzmocnić takie współistnienie. Wydaje się, że podejście Herdera i Gehlena stanowi bardziej odpowiedni wkład niż antropologia Kanta (i scholastyka). Odrodzenie tego paradygmatu jest możliwe tylko dzięki ogólnemu przewartościowaniu aksjologii związanych z niepełnosprawnością oraz postkonwencjonalizacji norm związanych z niepełnosprawnością.

Słowa kluczowe: niepełnosprawność, starożytna, średniowieczna i współczesna antropologia, wzrost i regresja, odrodzenie paradygmatu, Kant, Herder, Gehlen

\section{Summary}

\section{Anthropology and disability. The origins, shift and revival of the paradigm}

Firstly, the paper reconstructs the core stages of the anthropological reflection on the disabled human being condition. Each stage shows certain strengths but, at the same time, limitations, since, according to the thesis advocated by the author, the humankind has still not achieved an appropriate quality of the disabled and enabled individuals coexistence. Secondly, the paper examines modern philosophical anthropologies which could empower such a coexistence. Herder and Gehlen's approach seems to offer a more adequate contribution than Kant's (and scholastic) anthropology. The revival of the paradigm is only thinkable due to the overall transvaluation of disability-related axiologies and the postconventionalisation of the disability-related norms.

Keywords: disability, ancient, medieval and modern anthropology, growth and regression, revival of the paradigm, Kant, Herder, Gehlen 